The influence of substrates having various origins on a nutritive value of champignon mushrooms (Agaricus bisporus Imbach)

Utjecaj supstrata različitoga podrijetla na nutritivnu vrijednost šampinjona (Agaricus bisporus Imbach)

Romanjek Fajdetić, N., Popović, B., Parađiković, N., Lončarić, Z., Japundžić Palenkić, B.

Poljoprivreda/Agriculture

ISSN: 1848-8080 (Online)

ISSN: 1330-7142 (Print)

http://dx.doi.org/10.18047/poljo.25.1.2

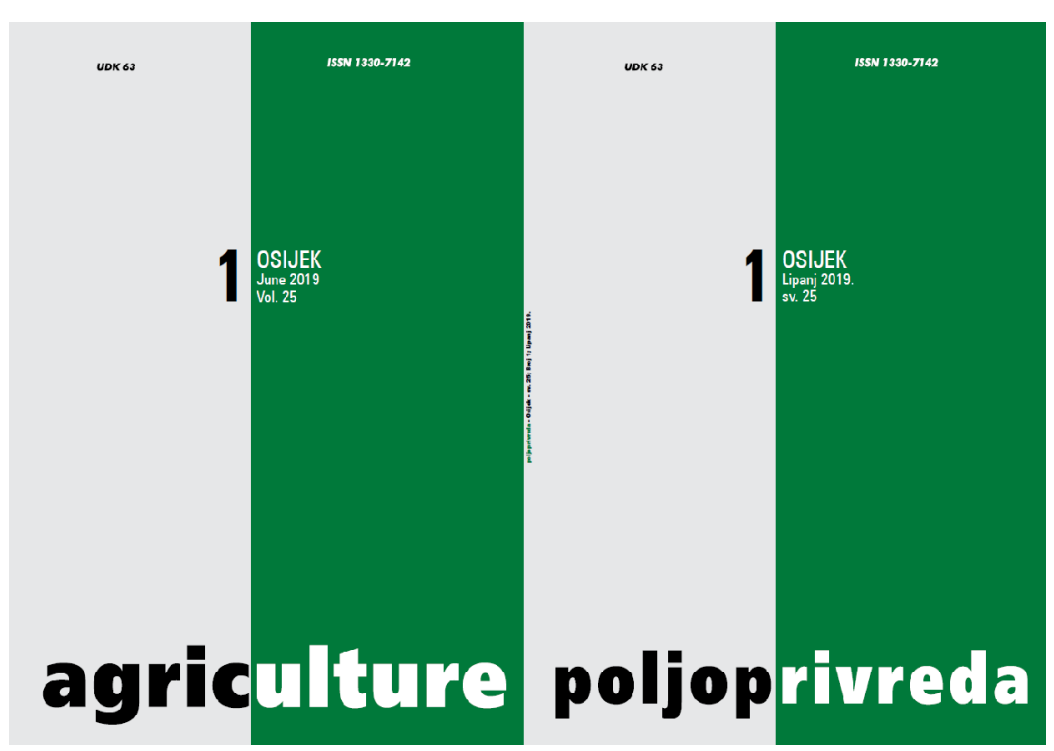

Fakultet agrobiotehničkih znanosti Osijek, Poljoprivredni institut Osijek

Faculty of Agrobiotechnical Sciences Osijek, Agricultural Institute Osijek 
ISSN 1330-7142

$U D K=635.8: 631.8$

DOI: $10.18047 /$ poljo.25.1.2

\section{THE INFLUENCE OF SUBSTRATES HAVING VARIOUS ORIGINS ON A NUTRITIVE VALUE OF CHAMPIGNON MUSHROOMS (Agaricus bisporus Imbach)}

Romanjek Fajdetić, N.(1), Popović, B. ${ }^{(2)}$, Parađiković, N.(2), Lončarić, Z..(2), Japundžić Palenkić, B. ${ }^{(1)}$

Original scientific paper

Izvorni znanstveni članak

\section{SUMMARY}

The metals such as $\mathrm{Fe}, \mathrm{Cu}, \mathrm{Zn}$ and $\mathrm{Mn}$ are the essential elements that have an important role in the human immune system. The aim of this research was to determine the concentration of nutritive values of macroelements ( $N, P$, and $K)$ and microelements (Fe and $\mathrm{Zn}$ ) in a mushroom substrate and in a champignon mushroom fruiting body. A trial was conducted in the mushroom production company Romanjek LLC in Slavonski Brod, Croatia. It was conducted in four vegetation cycles on two different substrates, the one originating from Eastern Europe and the other originating from Northern Europe. At the end of the trial, the basic chemical properties of substrates and mushrooms were recorded. A comparison of investigated substrate measurements demonstrates that the highest content of elements $N, P$, and $K$ was determined in the substrate 2 originating from Northern Europe, while the concentration of microelements $\mathrm{Fe}$ and $\mathrm{Zn}$ was higher in substrate 1, originating, from Eastern Europe. There was a statistically significant difference in a macroelement content in the mushrooms grown on the substrates of different origin, as well as in the transfer of $\mathrm{Zn}$ and Fe from a substrate to mushrooms. There was a higher accumulation of the transferred $\mathrm{Zn}$ in comparison to $\mathrm{Fe}$ in the mushrooms regardless of the origin of the substrate.

Key words: substrate, nutritive values, heavy metals, accumulation

\section{INTRODUCTION}

Champignon mushrooms are the most widely cultivated mushrooms in commercial production. According to liyama et al. (1994), the Agaricus bisporus substrate or compost is produced from a mixture of wheat straw ( $40-50 \%$ of the total dry weight), horse manure or stable bedding $(20-25 \%)$, poultry manure $(10-15 \%)$ and gypsum $(5-10 \%)$. Horse manure or stable bedding is only used in certain countries, where these ingredients are available in significant amounts. A substrate quality depends mostly on the quality of the aforementioned ingredients, and this directly affects the mushroom quality. According to Matilla et al. (2001), an increased interest in mushrooms and their use in a diet is not only caused by their medicinal and therapeutic properties but also by their taste, texture, and low caloric value. The metals such as $\mathrm{Fe}, \mathrm{Cu}, \mathrm{Zn}$ and $\mathrm{Mn}$ are the essential ones, having an important role in the immune system (Ünak et al., 2007). Compared with vegetables, mushrooms proved to be a good source of many mineral elements, e.g., the contents of $K, P, Z n$, and Cu varied in the ranges of $26.7-47.3 \mathrm{~g} / \mathrm{kg}, 8.7-13.9 \mathrm{~g} / \mathrm{kg}, 47-92 \mathrm{mg} / \mathrm{kg}$, and $5.2-35$ $\mathrm{mg} / \mathrm{kg} \mathrm{dw}$, respectively (Matilla et al., 2001). According to the Food and Agriculture Organization and the World Health Organization standards (2019), some mineral elements are required in very minute amounts in human diets for metabolic purposes; consequently, these are termed the "essential trace elements." Micronutrient

(1) Nataša Romanjek Fajdetić, Ph.D. (nrfajdetic@vusb.hr), Božica Japundžić Palenkić, Ph.D. - College of Applied Sciences in Slavonski Brod, Dr. M. Budaka 1, 35000 Slavonski Brod, Croatia, (2) Assoc. Prof. Brigita Popović, Ph.D., Prof. Nada Parađiković, Ph.D., Prof. Zdenko Lončarić, Ph.D. - Josip Juraj Strossmayer University of Osijek, Faculty of Agrobiotechnical Sciences Osijek, V. Preloga 1, 31000 Osijek, Croatia 
malnutrition affects $1 / 3^{-1 / 2}$ of global population. It causes an untold human suffering and levies huge costs on a society in terms of an unrealized human potential and a lost economic productivity (Miller and Welch, 2013). Iron $(\mathrm{Fe})$ is a component of hemoglobin and numerous enzymes. It carries oxygen and forms a part of hemoglobin in blood and myoglobin in muscles; equally, it is a component of various enzymes (Stein, 2010). Zn is an essential trace element not only for humans but for all organisms. It is a component of more than 300 enzymes and an even greater number of other proteins, which emphasizes its indispensable role in human health (Vallee and Falchuk, 1993). Zn is absorbed in a human organism mostly through food, and mushrooms are one of the best sources of $\mathrm{Zn}$. A research by Dogan et al. (2006) showed that a $\mathrm{Zn}$ concentration in fruiting bodies of edible mushrooms is considerably higher than in the plants (herbs, fruits, vegetables, crops). The daily value of zinc amounts to $15 \mathrm{mg}$ for adults and children aged four and older (U.S. Department of Agriculture, 2011). According to Bakan et al. (1993), an intake of $100 \mathrm{~g}$ of dried fruiting bodies of mushrooms (e.g., $B$. badius) provides about a half of the daily $\mathrm{Zn}$ requirement. According to Luzardo et al. (2015), a low dietary $\mathrm{K}^{+}$intake is increasingly recognized as a major drive in the pathogenesis of salt-sensitive hypertension. A low dietary $\mathrm{K}^{+}$intake may promote atherosclerosis through an increased vascular calcification and reactive oxygen species (Gritter et al., 2018). The aim of this study was to compare the transfer of macroelements (N, $\mathrm{P}$, and $\mathrm{K}$ ) and microelements ( $\mathrm{Fe}$ and $\mathrm{Zn}$ ) from the substrates to the mushrooms in respect to the different origin of the substrates.

\section{MATERIAL AND METHODS}

Experiment design and a mushroom-sample collecting

The trial was conducted in the mushroom production Romanjek LLC in Slavonski Brod, Croatia $\left(45^{\circ} 11^{\prime}\right.$ $\mathrm{N} ; 18^{\circ} 00^{\prime} \mathrm{E}$ ). The trial was divided in two substrates cycles. One originated from the eastern part of Europe (Substrate 1) and the other from the northern part of Europe (Substrate 2). The basic chemical properties of Substrate 1 were as follows: $\mathrm{pH}_{\mathrm{H} 20}$ (6.18), $\mathrm{EC} \mathrm{mS/}$ $\mathrm{cm}$ (8.35), DM (46.82), N (2.33), C (25.4), C/N (10.72), $P(1.70)$ and $K(1.02)$. The basics conducted concerning four vegetational chemical properties of Substrate 2 were as follows: $\mathrm{pH}_{\mathrm{H} 2 \mathrm{O}}(6.08), \mathrm{EC} \mathrm{mS/cm} \mathrm{(8.41),}$ DM (42.04), N (2.33), C (27.71), C/N (11.97), P (1.90) and $K(1.07)$. The experiment was set up in a split-plot design type in four repetitions. The analyses of basic chemical properties were performed on $36 \mathrm{~kg}$ (two briquettes) of mushroom substrate in four repetitions. The analysis was performed during four vegetational cycles, so that the whole research used 64 briquettes. The mushroom substrate was sampled 16 times (at the beginning and at the end of four harvests on two substrates). Five kilograms of samples were taken and divided in two subsamples for the sake of an analysis.
One part of the sample was dried in a drier at $75 \pm 2^{\circ} \mathrm{C}$ during 48 hours to obtain a constant weight according to the TMECC method (Test Methods for the Examination of Composting and Compost, Thompson, 2001), then homogenized, ground, sifted through a $1 \mathrm{~mm}$ sieve and stored in the paper bags in a desiccator. The rest of the sample was stored in the PE bags in the refrigerator at a temperature amounting to $5^{\circ} \mathrm{C}$. The mushrooms were sampled in three harvests during each vegetation cycle, 32 samples in each cycle. For analyses, $1500 \mathrm{~g}$ of mushrooms were delivered to the laboratory. After drying, the mushroom samples were ground by a heavy metal-free grinder (Retch RM 200) and stored in paper bags.

\section{Laboratory research}

Within a laboratory research, chemical analyses of substrates during vegetational cycles and chemical analyses of harvested mushrooms were performed.

\section{Chemical analysis of the substrate}

In the mushroom substrate samples, a total $\mathrm{N}$ content, $\mathrm{P}$ and $\mathrm{K}$ contents, and a concentration of microelements ( $\mathrm{Fe}$ and $\mathrm{Zn}$ ) were analyzed. In the paper, "content" was the expression used for the concentration of a dry or fresh matter, as it is accustomed in the literature. A basic solution for the determination of macro- and microelement concentration was obtained by digestion, with a mixture of 96-percent sulfuric acid and 4-percent perchloric acid and hydrogen peroxide (Vukadinović and Bertić, 1989). Furthermore, a nitrogen content was determined by the Kjeldahl method (EN 13654-1), while the $P$ content was determined by the yellow method (Vajnberger, 1966). The content of $K$ and the concentration of Fe and $\mathrm{Zn}$ were obtained by spectrometry on the AAS Perkin Elmer 2000 using a basic solution.

\section{Chemical analysis of mushrooms}

On the prepared dried mushroom samples, the following analyses were performed: a determination of the content of N, P, and $\mathrm{K}$ and the concentration of microelements ( $\mathrm{Fe}$ and $\mathrm{Zn}$ ). The determination of macroand microelement concentration in the sample was founded on the basic sample solution that was acquired by digestion with a mixture of 96 -percent sulfuric acid and 4-percent perchloric acid and hydrogen peroxide (Vukadinović and Bertić, 1989). The content of N was determined by the Kjeldahl method (EN 13654-1). The content of $P$ and $K$ and the concentration of $F e$ and $Z n$ in the basic sample solution were determined by the inductively coupled plasma (ICP Perkin Elmer Optima 2100 DV).

\section{Statistical analysis}

The results were statistically analyzed using the SAS 9.3 software for Windows (SAS Institute Inc., Cary, NC, USA). Significant differences were tested by the ANOVA using the Fisher tests were declared significant at the $p<0.01$ level. 


\section{RESULTS AND DISCUSSION}

The aim of the research was to determine a content of macroelements' ( $\mathrm{N}, \mathrm{P}$, and $\mathrm{K}$ ) nutritive values and a concentration of microelements ( $\mathrm{Fe}$ and $\mathrm{Zn}$ ) in a mushroom substrate and in the champignon mushroom fruiting body.

\section{Substrate analysis}

The content of macroelements and the concentration of microelements were determined during each vegetational cycle (Figure 1, Figure 2).

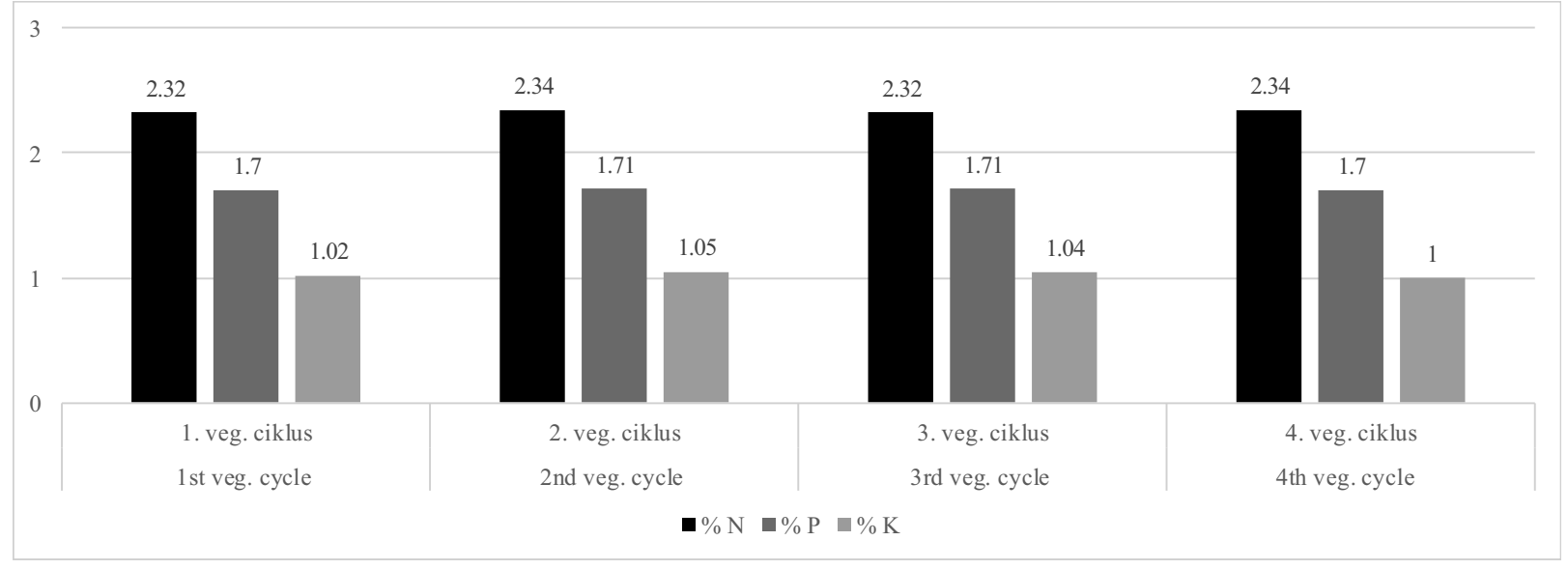

Figure 1. The content of the N, P, and K macroelements in Substrate 1.

Slika 1. Sadržaj makroelemenata N, P i K u supstratu 1.

Comparing the results of the researched substrates, it has been found out that the highest content of $\mathrm{N}, \mathrm{P}$, and $\mathrm{K}$ was determined in Substrate 2. The similar results were observed in the researches performed by other authors. According to Fidanza et al. (2010), the average concentration of $\mathrm{N}$ content in a substrate dedicated to the mushroom production amounted to $1.12 \%$ (wet condition) and $2.65 \%$ (dry condition), amounting to $0.29 \%$ (wet condition) and $0.69 \%$ (dry condition) for the $\mathrm{P}$ content, i.e. to $0.8 \%$ (wet condition) and $1.3 \%$ (dry condition) for the $\mathrm{K}$ content. Due to their chemical properties Zeljković et al. (2015) claimed that the deployed mushroom substrates may be used as an alternative to the commercial ones in the production of geranium and surfinia seedlings.

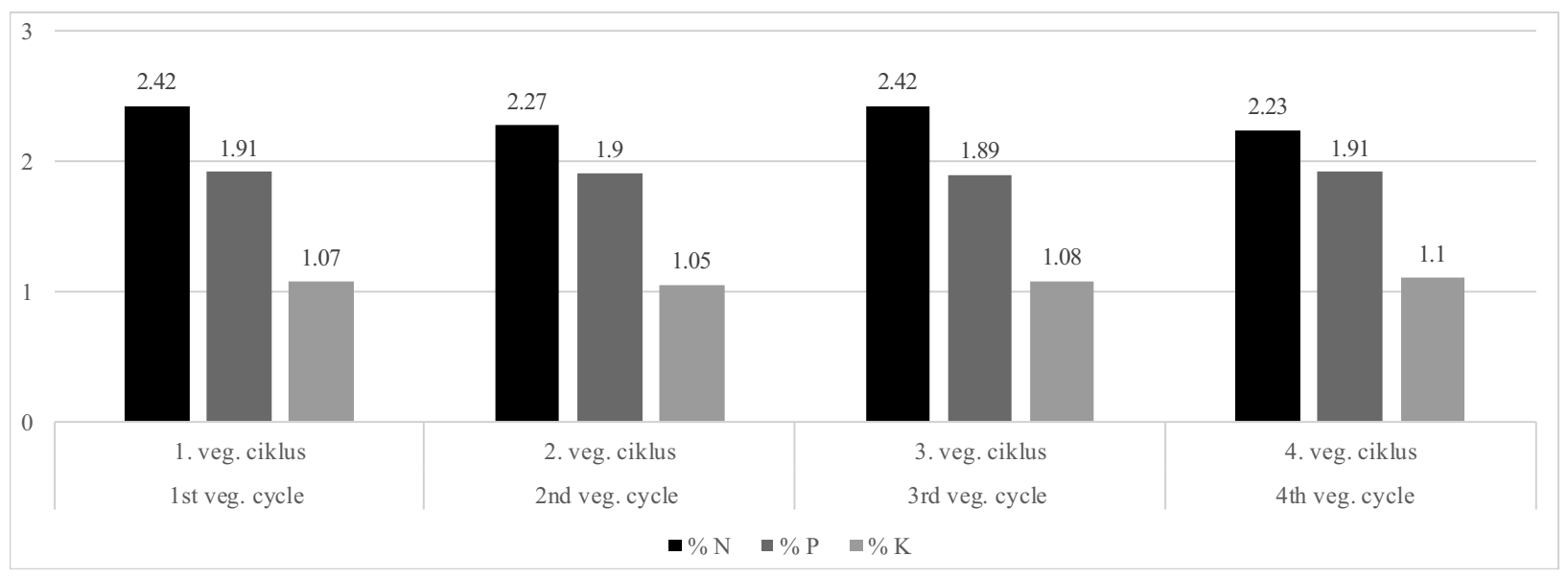

Figure 2. The content of macroelements N, P, and K in Substrate 2.

Slika 2. Sadržaj makroelemenata N, P i K u supstratu 2. 
The determined content of $P$ was very high in comparison to the other researchers' results (Fidanza et al., 2010), probably being a result of a growing technique or of the quality of chicken manure that was used in the mushroom substrate production. Lončarić et al. (2005) determined that, during the substrate decomposition process, the optimal changes of an organic matter, as well as the other chemical properties, depend on the content of a primary compost matter.

Table 1. The concentration of the Fe and $\mathrm{Zn}$ microelements $(\mathrm{mg} / \mathrm{kg})$ in the Substrate 1 and Substrate 2.

Tablica 1. Koncentracija esencijalnih mikroelemenata Fe i $\mathrm{Zn}(\mathrm{mg} / \mathrm{kg})$ u supstratu 1 i supstratu 2.

\begin{tabular}{|l|c|c|c|c|c|c|c|c|}
\hline & \multicolumn{2}{|c|}{$\begin{array}{l}\text { 1st vegetational cycle } \\
\text { 1. vegetacijsk ciklus }\end{array}$} & \multicolumn{2}{c|}{$\begin{array}{c}2^{\text {nd }} \text { vegetational cycle } \\
\text { 2. vegetacijski ciklus }\end{array}$} & \multicolumn{2}{c|}{$\begin{array}{c}3^{\text {rd }} \text { vegetational cycle } \\
\text { 3. vegetacijski ciklus }\end{array}$} & \multicolumn{2}{|c|}{$\begin{array}{c}4^{\text {th }} \text { vegetational cycle } \\
\text { 4. vegetacijski ciklus }\end{array}$} \\
\cline { 2 - 9 } & $\mathrm{Fe}$ & $\mathrm{Zn}$ & $\mathrm{Fe}$ & $\mathrm{Zn}$ & $\mathrm{Fe}$ & $\mathrm{Zn}$ & $\mathrm{Fe}$ & Zn \\
\hline $\begin{array}{l}\text { Substrate } \\
\text { Supstrat } \\
1\end{array}$ & $1317.94 \mathrm{a}$ & $163.32 \mathrm{a}$ & $2793.13 \mathrm{a}$ & $152.86 \mathrm{a}$ & $4055.64 \mathrm{a}$ & $155.55 \mathrm{a}$ & $4055.65 \mathrm{a}$ & $155.65 \mathrm{a}$ \\
\hline $\begin{array}{l}\text { Substrate } \\
\text { Supstrat } \\
2\end{array}$ & $1247.58 \mathrm{~b}$ & $145.61 \mathrm{~b}$ & $1242.22 \mathrm{~b}$ & $104.79 \mathrm{~b}$ & $1427.08 \mathrm{~b}$ & $121.55 \mathrm{~b}$ & $1677.20 \mathrm{~b}$ & $122.55 \mathrm{~b}$ \\
\hline $\begin{array}{l}\text { Average } \\
\text { Prosjek }\end{array}$ & 1282.76 & 154.46 & 2017.67 & 128.82 & 2741.36 & 138.55 & 2866.42 & 138.60 \\
\hline
\end{tabular}

Notes: The means followed by different letters are significantly different $(p<0.05)$

Razlike između vrijednosti u kolonama koje sadrže istu slovnu oznaku nisu statistički značajne

The results of microelement concentration demonstrated that the highest amount of Fe measured in Substrate 1 was in the fourth cycle, while the lowest one was in the first cycle. The highest measured amount of $\mathrm{Zn}$ was in the first cycle and the lowest amount thereof was in the second cycle (Table 1). The highest measured concentration of $\mathrm{Fe}$ in Substrate 2 was in the fourth cycle, while the lowest one was in the second cycle. Furthermore, the highest concentration of $\mathrm{Zn}$ in Substrate 2 was in the first cycle, while the lowest was in the second cycle (Table 1). Unlike the macroelement content, the results of a microelement concentration in both substrates show that the higher average concentrations of $\mathrm{Fe}$ and $\mathrm{Zn}$ were determined in Substrate 1 (Table 1).

\section{Mushroom analysis}

In order to determine the translocations of macroelements and the essential trace elements from a substrate to the champignon mushroom, the mushroom fruiting bodies were also analyzed (Table 2). At the same time, these results show the real nutritional values of mushrooms as a part of human diet.

Table 2. The content of macroelements in mushroom fruiting bodies grown on two substrates.

Tablica 2. Sadržaj makroelemenata u plodnom tijelu gljiva uzgojenih na dva supstrata.

\begin{tabular}{|c|c|c|c|c|}
\hline $\begin{array}{l}\text { Growing month } \\
\text { Mjesec uzgoja }\end{array}$ & $\begin{array}{l}\text { Macroelements (\%) } \\
\text { Makroelementi (\%) }\end{array}$ & $\begin{array}{l}\text { Substrate } 1 \\
\text { Supstrat } 1\end{array}$ & $\begin{array}{c}\text { Substrate } 2 \\
\text { Supstrat } 2\end{array}$ & $\begin{array}{l}\text { Average } \\
\text { Prosjek }\end{array}$ \\
\hline \multirow{3}{*}{$\begin{array}{l}1^{\text {st }} \text { vegetational cycle } \\
\text { 1. vegetacijski ciklus }\end{array}$} & $\mathrm{N}$ & $8.63 \mathrm{a}$ & $7.36 \mathrm{~b}$ & 7.99 \\
\hline & $P$ & $10.09 \mathrm{a}$ & $11.17 \mathrm{~b}$ & 10.63 \\
\hline & K & $4.23 \mathrm{a}$ & $3.67 \mathrm{~b}$ & 3.95 \\
\hline \multirow{3}{*}{$\begin{array}{l}2^{\text {nd }} \text { vegetational cycle } \\
\text { 2. vegetacijski ciklus }\end{array}$} & $\mathrm{N}$ & $7.81 \mathrm{a}$ & $7.14 \mathrm{a}$ & 7.47 \\
\hline & $P$ & $10.75 \mathrm{a}$ & $10.74 \mathrm{a}$ & 10.74 \\
\hline & K & $4.10 \mathrm{a}$ & $4.00 \mathrm{a}$ & 4.05 \\
\hline \multirow{3}{*}{$\begin{array}{l}3^{\text {rd }} \text { vegetational cycle } \\
\text { 3. vegetacijski ciklus }\end{array}$} & $\mathrm{N}$ & $7.28 \mathrm{a}$ & $7.96 \mathrm{a}$ & 7.62 \\
\hline & $P$ & $11.61 \mathrm{a}$ & $11.77 \mathrm{a}$ & 11.69 \\
\hline & K & $4.23 \mathrm{a}$ & $4.07 \mathrm{a}$ & 4.15 \\
\hline \multirow{3}{*}{$\begin{array}{l}4^{\text {th }} \text { vegetational cycle } \\
\text { 4. vegetacijski ciklus }\end{array}$} & $\mathrm{N}$ & $7.34 \mathrm{a}$ & $7.40 \mathrm{a}$ & 7.37 \\
\hline & $P$ & $11.13 \mathrm{a}$ & $11.99 \mathrm{a}$ & 11.56 \\
\hline & K & $4.27 \mathrm{a}$ & 3.98 a & 4.12 \\
\hline
\end{tabular}

Notes: The means followed by different letters are significantly different $(p<0.05)$

Razlike između vrijednosti u kolonama koje sadrže istu slovnu oznaku nisu statistički značajne 
The results of macroelement content showed that the statistically significant differences between two substrates were established only in the first vegetational cycle. Also, the content of macroelements in mushrooms was in accordance with the results recorded in the research by Mattila et al. (2002), who reported that the content of $\mathrm{N}$ in Agaricus bisporus (brown) was from $7.7 \%$ to $8.4 \%$. Pursuant to the Food Composition Database (USDA 11260), fresh mushrooms are a good source of the dietary mineral phosphorus ( $12 \%$ daily value) and potassium (7\% daily value). According to Xu et al. (2011), many mushrooms are the excellent sources of protein due to a low-fat content and the absence of choles- terol. There are various mushroom proteins with the interesting biological activities, such as the lectins, fungal immunomodulatory proteins (FIP), ribosome inactivating proteins (RIP), ribonucleases, laccases, and other proteins, which have become the popular sources of natural antitumor, antiviral, antimicrobial, antioxidative, and immunomodulatory agents. Moura et al. (2007) argued that mushroom cultivation, due to its high nutritional value, is a good alternative to the supply of humans with a protein-rich food in the countries where the alimentary value is very low. The next point of interest was to determine a concentration of the essential trace elements ( $\mathrm{Fe}$ and $\mathrm{Zn}$ ) in mushrooms (Table 3).

Table 3. The concentration of microelements $\mathrm{Fe}$ and $\mathrm{Zn}(\mathrm{mg} / \mathrm{kg})$ in the mushrooms picked up on Substrates $\mathbf{1}$ and 2.

Tablica 3. Koncentracija esencijalnih mikroelemenata Fe i $\mathrm{Zn}(\mathrm{mg} / \mathrm{kg})$ u gljivama ubranim na supstratima 1 i 2.

\begin{tabular}{|c|c|c|c|c|c|c|c|c|}
\hline & \multicolumn{2}{|c|}{$\begin{array}{l}1^{\text {st }} \text { vegetational cycle } \\
\text { 1. vegetacijski ciklus }\end{array}$} & \multicolumn{2}{|c|}{$\begin{array}{l}2^{\text {nd }} \text { vegetational cycle } \\
\text { 2. vegetacijski ciklus }\end{array}$} & \multicolumn{2}{|c|}{$\begin{array}{l}3^{\text {rd }} \text { vegetational cycle } \\
\text { 3. vegetacijski ciklus }\end{array}$} & \multicolumn{2}{|c|}{$\begin{array}{l}4^{\text {th }} \text { vegetational cycle } \\
\text { 4. vegetacijski ciklus }\end{array}$} \\
\hline & $\mathrm{Fe}$ & $\mathrm{Zn}$ & $\mathrm{Fe}$ & $\mathrm{Zn}$ & $\mathrm{Fe}$ & $\mathrm{Zn}$ & $\mathrm{Fe}$ & $\mathrm{Zn}$ \\
\hline $\begin{array}{l}\text { Substrate } \\
\text { Supstrat } \\
1\end{array}$ & 103.6a & $100.27 a$ & 103.77a & $102.04 a$ & $113.12 a$ & $100.69 a$ & $117.12 \mathrm{a}$ & $105.39 a$ \\
\hline $\begin{array}{l}\text { Substrate } \\
\text { Supstrat } \\
2\end{array}$ & $79.02 b$ & $79.42 b$ & $87.93 b$ & $90.56 b$ & $88.42 b$ & $89.72 b$ & $112.53 b$ & $9.53 \mathrm{~b}$ \\
\hline $\begin{array}{l}\text { Average } \\
\text { Prosjek }\end{array}$ & 91.32 & 89.84 & 95.85 & 96.30 & 100.77 & 95.20 & 114.82 & 98.46 \\
\hline
\end{tabular}

Notes: Means followed by different letters are significantly different $(p<0.05)$

Razlike između vrijednosti u kolonama koje sadrže istu slovnu oznaku nisu statistički značajne

Comparing a concentration of the essential microelements in mushrooms harvested on two substrates, the results signified higher concentrations of $\mathrm{Fe}$ and $\mathrm{Zn}$ in Substrate 1 as a direct consequence of the substrate origin (Table 3). The results obtained are similar to the ones recorded by Moura et al. (2007), who established the concentrations of Fe amounting to $220 \mathrm{mg} / \mathrm{kg}$ and of $\mathrm{Zn}$ amounting to $63 \mathrm{mg} / \mathrm{kg}$ in a substrate. According to the Food and Agriculture Organization and World Health Organization standards, an acceptable daily intake of the microelement $\mathrm{Fe}$ is $48 \mathrm{mg}$ and amounts to $15 \mathrm{mg}$ for $\mathrm{Zn}$, respectively. Bakan et al. (2001) have found that a consumption of $100 \mathrm{~g}$ of the dried mushroom fruiting bodies (e.g., of the $B$. badius) provides for about a half of the daily $\mathrm{Zn}$ requirement. This research has shown that the required daily intake of the essential trace elements may be accomplished by mushroom consumption. The extent of $\mathrm{Zn}$ transfer from soil to the mushroom was species specific and influenced by the availability of these two heavy metals, as well as by the age of the mushroom itself (Thomet et al., 1999). It is known that the heavy metals in high concentrations inhibit the development of the mycelium, but there are some heavy metals that stimulate the growth of the mycelia, such as $\mathrm{Zn}$ and Fe (Nilanjana Das, 2005). A research by Dogan et al. (2006) showed that $Z n$ concentrations in fruiting bod- ies of edible mushrooms are considerably higher than those in plants (herbs, fruits, vegetables, crops), as was confirmed through the results of this research. When the essential element concentrations in the substrates and in the mushrooms are compared, it is observable that there are the positive transfers from the substrates to the mushrooms. It was determined that a $\mathrm{Zn}$ transfer was higher than the Fe one (Table 1 and Table 3). The research by Semreen and Aboul-Enein (2011) showed that the heavy metal contents in all mushroom species were lower than in the soil substrates, and that was confirmed by this research.

\section{CONCLUSION}

The concentration of macroelements ( $\mathrm{N}, \mathrm{P}$, and $\mathrm{K}$ ) and of the microelements $(\mathrm{Zn}$ and $\mathrm{Fe})$ in a mushroom fruit was correlated to the macroelements $(N, P$ and $\mathrm{K})$ and microelements ( $\mathrm{Zn}$ and $\mathrm{Fe})$ in the substrate. A statistically significant difference in the concentration of macroelements ( $N, P$, and $K$ ) in the substrates of different origin, as well as in the mushrooms harvested from them, was found only in the first vegetational cycle. A statistically significant difference in the concentration of microelements ( $\mathrm{Zn}$ and $\mathrm{Fe})$ in the substrates of different origin, as well as in the mushrooms harvested 
from them, was found in the all vegetational cycles. There was a difference in the transfer of $\mathrm{Zn}$ and Fe from a substrate to the mushroom, and there was a higher accumulation of $\mathrm{Zn}$ in comparison to that of the $\mathrm{Fe}$ in mushrooms.

A medicinal and agronomical multidisciplinary approach to the mushroom research has an enormous potential due to the mushrooms' great health benefits and a high nutritional value. Although the mushroom consumption in Croatia is still very low in comparison to other European countries, there is an awareness about their positive effects on human health.

\section{REFERENCES}

1. Bakan, R., Birmingham, C. L., Aeberhardt, L., \& Goldner, E. M. (1993). Dietary zinc intake of vegetarian and nonvegetarian patients with anorexia nervosa. International Journal of Eating Disordorders, 13(2), 229-233.

2. Das, N. (2005). Heavy metals biosorption by mushrooms. Natural Product Radiance, 4(6), 454-459.

3. Dogan, H. H, Sanda, A., Uyanoz, R., Ozturk, C., \& Cetin, U. (2006). Contents of metals in some wild mushrooms its impact in human health. Biological Trace Element Research, 110(1), 79-94.

https://doi.org/10.1385/BTER:110:1:79

4. EN13654-1: Determination of Kjeldahl Nitrogen in soil, biowaste and sewage sludge. Retrieved from https:// www.ecn.nl/docs/society/horizontal/STD6161_Kj-N.pdf

5. Fidanza, M. A., Sanford, D. L., Beyer, D. M., \& Aurentz, D. J. (2010). Analysis of fresh mushroom compost. HortTechnology, 20(2), 449-453.

6. Food and Agriculture Organization and World Health Organization Standards. (1993). Evaluation of certain food additives and contaminants, WHO Technical Report Series 837. Geneva: WHO.

7. Food and Agriculture Organization and World Health Organization Standards. (2019). Retrieved from https:// www.fao.org/ag/humannutrition/nutrition/66322/en/

8. Food and Agriculture Organization and World Health Organization Standards. Expert Committee on Food Additives, Summary and conclusions. (1999). In: $53^{\text {rd }}$ Meeting. Rome. Geneva: WHO.

9. Gritter, M., Rotmans, J. I., \& Hoorn, E. J. (2018). Role of dietary $\mathrm{K}^{+}$in Natriuresis, Blood Pressure Reduction, Cardiovascular Protection and Renoprotection. Hypertension, 73(1), 15-23 https://doi.org/10.1161/HYPERTENSIONAHA.118.11209

10. liyama, K., Stone, B. A., \& Macauley, B. J. (1994). Compositional changes in compost during composting and growth of Agaricus bisporus. Applied and Environmental Microbiology, 60(5), 1538-1546.

11. Lončarić, Z., Karalić, K., Vukadinović, V., Bertić, B., \& Kovačević, V. (2005). Variation of liming recommendation caused by calculation approach. Plant Nutrition for Food Security, Human Health and Environmental Protection. Tsinghua University Press. Beijing, China, 1042-1043.
12. Luzardo, L., Noboa, O. \& Boggia, J. (2015). Mechanisms of salt-sensitive hypertension. Current Hypertension Reviews, 11(1), 14-21.

13. Mattila, P., Könkö, K., Eurola, M., Pihlava, J. M., Astola, J., Vahteristo, L., \& Piironen, V. (2001). Contents of vitamins, mineral elements, and some phenolic compounds in cultivated mushrooms. Journal of Agricultural and Food Chemistry, 49(5), 2343-2348. https://doi.org/10.1021/jf001525d

14. Mattila, P., Salo-Väänänen, P., Könkö, K., Aro, H., \& Jalava, T. (2002). Basic composition and amino acid contents of mushrooms cultivated in Finland. Journal of Agricultural and Food Chemistry, 50(22), 6419-6422. https://doi.org/10.1021/jf020608m

15. Miller, D., \& Welch, R. M. (2013). Food system strategies for preventing micronutrient malnutrition. Food Policy, 42: 115-128. https://doi.org/10.1016/j.foodpol.2013.06.008

16. Moura, P. L. C., Maihara, V. A., Castro, L. P., \& Figueira, R. C. L. (2007). Essential trace elements in edible mushrooms by neutron activation analysis. In Proceedings of the 2007 International Nuclear Atlantic Conference (INAC), Santos, SP, Brazil.

17. Parađiković, N., Zeljković, S., Tkalec, M., Vinković, T., Maksimović, I. \& Haramija, J. (2016). Influence of biostimulant application on growth, nutrient status and proline concentration of begonia transplants, Biological Agriculture \& Horticulture, 33(6), 89-96. https://doi.org/10.1080/01448765.2016.1205513

18. Patterson, K. Y., Holbrook, J. T., Bodner, J. E., Kelsay, J. L., Smith, J. C., \& Veillon, Jr. C. (1984). Zinc, copper and manganese intake and balance for adults consuming self-selected diets. The American Journal of Clinical Nutrition, 40(6), 1397-1403. https://doi.org/10.1093/ajcn/40.6.1397

19. SAS 9.3: SAS Institute Inc. Cary, NC, USA.

20. Semreen, M.H., \& Aboul-Enein, H. (2011). Determination of heavy metal content in wild-edible mushroom from Jordan. Journal Analytical Letters, 44(5), 932-941. https://doi.org/10.1080/00032711003790072

21. Sharma, H. S., \& Kilpatrick, M. (2000). Mushroom (Agaricus bisporus) compost quality factors for predicting potential yield of fruiting bodies. Canadian Journal of Microbiology, 46(6), 515-519. https://doi.org/10.1139/w00-012

22. Stein, A. (2010). Global impacts of human mineral malnutrition. Plant and Soil, 335(1-2), 133-154.

23. Stihi, C., Radulescu, C., Busuioc, G., Popescu, I. V, Gheboianu, A., \& Ene, A. (2009). Studies on accumulation of heavy metals from substrate to edible wild mushrooms. Romanian Journal of Physics, 56(1-2), 257264.

24. Thomet, U., Vogel, E., \& Krahenbuhl, U. (1999). The uptake of cadmium and zinc by mycelia and fruiting bodies of edible mushrooms, European Food Research and Technology, 209(5), 317-324. https://doi.org/10.1007/s002170050502

25. Thompson, W. H., Leege, P. B., Millner, P., \& Watson, M. E. (2002). Test methods for the examination of com- 
posting and compost USDA U.S. Government Printing Office. Retrieved from https://tmecc.org/tmecc/index. html

26. Ünak, P., Yurt Lambrecht, F., Biber, F., \& Darcan, S. (2007). lodine measurements by isotope dilution analysis in drinking water in Western Turkey. Journal of Radioanalytical and Nuclear Chemistry, 273(3), 649-651. https://doi.org/10.1007/s10967-007-0925-3

27. U.S. Department of Agriculture, Agricultural Research Service. (2011). USDA National Nutrient Database for Standard Reference, Release 24. Nutrient Data Laboratory Home Page. Retrieved from https://www.ars. usda.gov/ba/bhnrc/ndl

28. USDA Food Composition Database.11260 Mushrooms, white, raw. Retrieved from https://ndb.nal.usda.gov/

29. Vallee, B. L., \& Falchuk, K. H. (1993). The biochemical basis of zinc physiology. Physiological Reviews, 73(1), 79-118.
30. Vajnberger, A, (1966). Land examination handbook Book I, Chemical testing methods, Determination of resinous phosphorus and potassium in soil. The Yugoslav society for soil study, 184-188.

31. Vukadinović, V., \& Bertić, B. (1989). Agrochemical and nutrition plant practicum, Faculty of Agriculture in Osijek, Osijek, 15-17.

32. Zeljković, S., Parađiković, N., Šušak, U., \& Tkalec, M. (2015, January). Use of spent mushroom substrate for growing geranium (Pelargonium peltatum L.) and surfinia (Petunia hybrida Juss.) seedlings. In Sixth International Scientific Agricultural Symposium "Agrosym 2015", Jahorina, Bosnia and Herzegovina, October 15-18, 2015. Book of Proceedings (pp. 109-114). University of East Sarajevo.

33. Xu, X., Yan, H., Chen, J., \& Zhang, X. (2011). Bioactive proteins from mushrooms. Biotechnology Advances, 29(6), 667-674.

https://doi.org/10.1016/j.biotechadv.2011.05.003

\section{UTJECAJ SUPSTRATA RAZLIČITOGA PODRIJETLA NA NUTRITIVNU VRIJEDNOST ŠAMPINJONA (Agaricus bisporus Imbach)}

\section{SAŽETAK}

Šampinjoni su jedna od ekonomski najznačajnijih jestivih vrsta gljiva, iznimno dobre nutritivne vrijednosti, koja ima važnu ulogu u zdravoj prehrani. Metali Fe, Cu, Zn i Mn su esencijalni elementi koji imaju važnu ulogu u jačanju ljudskoga imuniteta. Cilj ovoga istraživanja bio je utvrditi koncentracije makroelemenata (N, P i K) i mikroelemenata (Fe i Zn) u supstratima i plodnim tijelima gljiva. Pokus je postavljen u proizvodnji gljiva Romanjek d. o. o. (Slavonski Brod, Hrvatska) i provodio se tijekom četiri vegetacijska ciklusa na dva supstrata različitoga geografskog podrijetla. Jedan supstrat (supstrat 1) proizveden je u istočnoj Europi, a drugi (supstrat 2) u sjevernoj Europi. Na kraju pokusa analizirana su osnovna kemijska svojstva supstrata i uzoraka istraživanih gljiva. Usporedbom rezultata istraživanih supstrata ustanovljen je veći sadržaj N, P i K u supstratu 2 podrijetlom sa sjevera Europe, ali je koncentracija mikroelemenata Fe i Zn bila veća u supstratu 1, podrijetlom s istoka Europe. Statistički značajna razlika ustanovljena je u sadržaju makroelemenata u gljivama uzgojenim na supstratima različitoga podrijetla, kao $i$ u transferu Zn i Fe iz supstrata u gljive. Osim toga, uspoređujući akumulaciju transferiranoga $Z n$ i Fe, ustanovljena je veća akumulacija Zn u gljivama bez obzira na podrijetlo supstrata.

Ključne riječi: supstrat, nutritivna vrijednost, teški metali, akumulacija

(Received on October 16, 2018; accepted on March 20, 2019. - Primljeno 16. listopada 2018.; prihvaćeno 20. ožujka 2019.) 